\title{
Internal Social Capital and the Attraction of Early Contributions in Crowdfunding
}

\author{
Massimo G. Colombo \\ Chiara Franzoni \\ Cristina Rossi-Lamastra
}

The nascent crowdfunding literature has highlighted the existence of a self-reinforcing pattern whereby contributions received in the early days of a campaign accelerate its success. After discussing what sustains this pattern, we maintain that the internal social capital that proponents may develop inside the crowdfunding community provides crucial assistance in igniting a self-reinforcing mechanism. Results of an econometric analysis of a sample of 669 Kickstarter projects are consistent with this view. Moreover, the effect of internal social capital on the success of a campaign is fully mediated by the capital and backers collected in the campaign's early days.

I continue to be overwhelmed by the positive feedback and enthusiasm from the support I have gotten from Kickstarter. The groundswell of people cheering us on and the evangelism - people spreading the word-is unlike anything I have experienced. In fact, I would say the last week was the high water mark of my career.

Brian Fargo, Founder of InXile Entertainment ${ }^{1}$

\section{Introduction}

A rapidly increasing number of entrepreneurial initiatives by both individuals and firms obtain capital through crowdfunding campaigns (The Economist, 2013). These campaigns involve "an open call, mostly through the Internet, for providing financial resources either in the form of a donation or in exchange for the future product or some form of reward" (Belleflamme, Lambert, \& Schwienbacher, 2014, p. 7). According to the last Crowdfunding Industry Report, crowdfunding initiatives collectively raised 2.7

Please send correspondence to: Chiara Franzoni, tel.: +39-02-2399-4823; e-mail: chiara.franzoni@ polimi.it, to Massimo G. Colombo at massimo.colombo@ polimi.it, and to Cristina Rossi-Lamastra at cristina1.rossi@ polimi.it.

1. Comment posted March 21, 2012, for the "Wasteland 2" campaign. https://www.kickstarter.com/projects/ inxile/wasteland-2/posts/193810, accessed March 31, 2014. 
billion dollars in 2012, an increase of more than $80 \%$ over $2011 .^{2}$ Despite the growing popularity of crowdfunding, scholarly understanding of the phenomenon is currently limited. Initial contributions have focused on defining and distinguishing crowdfunding from partially different phenomena (Hildebrand, Puri, \& Rocholl, 2013), such as crowdsourcing (Afuah \& Tucci, 2012), online charity donations, and peer-to-peer lending (Zhang \& Liu, 2012). Taxonomies of crowdfunding models have been proposed based on what backers receive in exchange for their contributions (Griffin, 2012), such as equity shares (Ahlers, Cumming, Günther, \& Schweizer, 2012), a product or service (Belleflamme et al., 2014), a particular interest rate (Zhang \& Liu, 2012), or simply gratification from the achievement of a mutually desired goal (Kappel, 2009).

A promising research strand has begun to explore the determinants of the success of crowdfunding campaigns. Success in "all-or-nothing" models of crowdfunding is reached when a project collects capital equal to or greater than the target amount. Anecdotal and descriptive evidence suggests that receiving contributions immediately after the start of a project largely anticipates the success of the campaign (e.g., Agrawal, Catalini, \& Goldfarb, 2014; Ordanini, Miceli, Pizzetti, \& Parasuraman, 2011). Similar patterns have been reported in other online contexts, such as peer-to-peer lending (Zhang \& Liu, 2012) and web auctions (Kauffman, Lai, \& Lin, 2011). Nonetheless, there has been no comprehensive discussion of the mechanisms that make early contributions so crucial for the success of crowdfunding campaigns. More importantly, we know little about what leads to the attraction of early contributions. The present paper intends to contribute to filling both of those gaps.

First, we discuss and empirically analyze the relationship between the contributions received shortly after the launch of a project and the ultimate success of the crowdfunding campaign. Prior studies have underpinned the self-reinforcing mechanism triggered by large pledges of money in the early days of a campaign (see again Agrawal et al., 2014, for a recent discussion) but have devoted less attention to whether a project has a substantial number of backers (see Kuppuswamy \& Bayus, 2013, for an exception). In this study, we investigate both types of support-capital and backers - and quantitatively assess how closely the two are associated with the final success of a campaign.

Second, this paper contributes to the current debate on the role of social capital in crowdfunding and more generally in seed financing (Shane \& Cable, 2002; Shane \& Stuart, 2002) by analyzing how social capital helps to attract contributions in the very early days of a campaign under conditions of maximum uncertainty. Previous works have pointed to the importance of the external social capital represented by family and friends (Agrawal, Catalini, \& Goldfarb, 2011) and by personal acquaintances, including those mediated by social media (e.g., Facebook contacts, Mollick, 2014). Our specific contribution is to highlight that the use of crowdfunding platforms enables proponents to leverage not only their external social capital, but also an additional stock of social capital specifically built within the crowdfunding community. Our key intuition is that crowdfunding platforms are not only intermediaries of monetary transactions, but also loci of social connections. We maintain that feelings of mutual identification and unwritten social norms of (specific and generalized) reciprocity build social capital relations among platform members, leading them to show support to other members. We call the social capital that can be leveraged through participation in the internal community of crowdfunders internal social capital and hold it distinct from external social capital (Adler \& Kwon, 2002, p. 19; Gedajlovic et al., 2013). To the best of the authors' knowledge, no prior work has investigated the social connections that project proponents develop within crowdfunding platforms with other members of the same community. We argue that

2. http://research.crowdsourcing.org/2013cf-crowdfunding-industry-report, accessed July 24, 2013. 
proponents establish relationships through behaviors specific to the crowdfunding community, such as inspecting, funding, and giving feedback to other proponents' projects. We then formulate the hypothesis that proponents' internal social capital deploys its value in the initial days of a project, when uncertainty surrounding the project discourages pledges from the general public and is essential to trigger a "success-breeds-success" process.

We test our hypotheses on data from Kickstarter.com. We use a sample of 669 projects started during the fall of 2012, which we follow from inception to closure. The econometric estimates fully support our contentions that internal social capital is positively associated with both the amount of early capital and the number of early backers, and that the positive relation between internal social capital and the probability of project success is fully mediated by these two variables. We control for external social capital and confirm its effect on the attraction of early contributions. We also show that external social capital has no direct effect on success and find that the effect of external social capital on early contributions is smaller in magnitude than the effect of internal social capital.

The paper is organized as follows. The next section presents the conceptual background and research hypotheses, followed by a presentation of the data and methodology. We next illustrate the econometric models and empirical results and discuss the robustness of the estimates. The final section discusses implications for scholars and practitioners.

\section{Conceptual Background}

\section{The Crucial Role of Early Contributions in the Success of Crowdfunding Projects}

It is conventional wisdom that what happens at the beginning of a community has a crucial impact on its subsequent evolution. In general, the existence of many early participants triggers even more participation. Conversely, when initial participants are few, an initiative's fate is cursed; a lack of early participants generates a negative, though often unmotivated, expectation. This idea dates back to the seminal work of Schelling (1978), who illustrates his reasoning using two specific examples: Saturday-morning seminar cycles organized by Harvard's faculty and spontaneous volleyball matches improvised in grassy areas of the campus (Schelling, 1978, p. 154). Schelling notes that if a large number of participants gather the first time an event is held, then a larger crowd is likely to gather the next day. Conversely, if few people participate at the beginning of an event-no matter how good it is - the event is fated to attract fewer and fewer participants. This rule has been documented in both the real world and in online communities, including the cases of purchase of books from Amazon.com (Cheng, Wang, \& Xie, 2011), software downloads (Duan, Gu, \& Whinston, 2009), microlending (Zhang \& Liu, 2012), and the development of open source software (Oh \& Jeon, 2007). Crowdfunding is no exception. Broad anecdotal and descriptive evidence indicates that early contributions largely anticipate the success or failure of fundraising campaigns. In this section, we extensively discuss why this pattern arises. Our primary insight is that early contributions reassure backers when they face high uncertainty at the outset of crowdfunding campaigns.

Our starting point is to recognize that there are several different sources of uncertainty at the beginning of a crowdfunding campaign. One major source of uncertainty relates to the quality of a project and its real chance of success (Agrawal et al., 2014). Potential backers are usually unsure of proponents' abilities and do not know whether proponents are trustable. For example, it is known that the great majority (approximately 75\%) of Kickstarter-funded projects deliver only after considerable delay, and some (approximately 4\%) do not deliver at all (Mollick, 2014). Therefore, considerations of quality and trustworthiness are important 
when deciding to support a project. These information asymmetries are common in the funding of innovative projects and have been extensively documented in the literature on innovation finance (see, e.g., Hall, 2002). In the case of crowdfunding, however, an additional source of uncertainty lies in the fact that most projects begin as works in progress that proponents post not only to raise money, but also to receive suggestions from the crowd (Gerber, Hui, \& Kuo, 2012). During the course of a campaign, feedback is progressively incorporated, as witnessed by frequent webpage updates. Whereas at the beginning of a campaign a project is often shaky, it grows progressively closer to the needs of the crowd as it approaches its deadline (Kuppuswamy \& Bayus, 2013).

We argue that contributions received in the very first stage of a crowdfunding campaign reduce uncertainty by means of three main mechanisms. First, information on support received in the early days of a crowdfunding campaign provides an indirect clue about project quality that triggers imitating behavior. This mechanism, known as observational learning (Bikhchandani, Hirshleifer, \& Welch, 1998), occurs when the quality of a product is not directly observable, and individuals derive information from merely looking at the behavior of others. When individuals see that many people have decided to purchase a certain product, they are induced to believe that the product is good and should be purchased (Banerjee, 1992; Cai, Chen, \& Fang, 2009; Markus, 1990). Observational learning has been found to occur in online auctions (Simonsohn \& Ariely, 2008), electronic microloan markets (Zhang \& Liu, 2012), online purchase of software programs (Duan et al., 2009), and music (Salganik, Dodds, \& Watts, 2006). Observational learning has been in place since the advent of trade, but now the Internet offers an ideal environment for it because webpages can immediately make other consumers' choices visible, including choices by consumers that the acquirer does not know in person (Cheng et al., 2011). Crowdfunding embeds the same features. In crowdfunding platforms, the amount of capital collected by a project and the number of people who have already backed it are usually highly visible. For instance, Kickstarter displays that information on the top right of its project pages, so that visitors are immediately aware in real time of how many people have endorsed a project and what share of the target capital has been raised. In the absence of better information, these statistics invite conjectures about the (unknown) quality of the project. A sizable amount of early capital and numerous early backers are hints that many have already scrutinized the project, liked it, and trusted its proponents and their ability to successfully complete the project.

Moreover, pledging a project that seems likely to succeed is more appealing than pledging one that seems likely to fail because pledging costs time and resources. Backers must register on a platform, understand a project's financing terms, and activate an online payment system. After pledging, the transaction does not take place immediately, but the money is nonetheless hold in an escrow account and cannot be used for other purposes (Hemer, 2011). Therefore, pledging an unsuccessful project results in wasted time.

Second, although both early capital and early backers enable observational learning, the latter also generate word-of-mouth (Arndt, 1967) around a project. To the extent that early backers talk about the backed project with their friends, more early backers mean more friends and more friends of friends informed. A fundamental lever of marketing, word-of-mouth has acquired new significance in the context of online communities (Dellarocas, 2003), with the assistance of social network functionalities embedded in websites. For instance, Kickstarter project pages contain "Tweet" and "Facebook" buttons that enable users to circulate information to their friends effortlessly.

Third, as mentioned earlier, crowdfunding projects are often underdeveloped at the time they are posted for funding. Looking at crowdfunding platforms, it is immediately apparent that early backers offer suggestions and feedback that proponents use to modify 
their projects continuously during a campaign. This feedback allows proponents to anticipate problems, to know their customers' preferences, and to meet the needs of a broader audience. An example best illustrates this point. The developers of a bag capable of recharging electronic devices while in motion were warned by the initial backers of their crowdfunding campaign that the recharger with which they were planning to equip the bag was not compatible with the electrical voltage used in several countries. This feedback allowed the proponents to identify an important technical problem that certainly would have emerged later on and that most likely would have constrained support from a part of their intended market. The proponents worked out a solution and posted a product update to reassure foreign customers that the product could be used abroad. ${ }^{3}$ This example suggests that a larger number of early backers mean potentially more feedback, more debugging, and more opportunities to fine-tune a product similar to what happens in open source software projects (von Krogh, Rossi-Lamastra, \& Heafliger, 2012). Consequently, projects with numerous early backers are more likely to consolidate in forms that meet the consensus of the crowd, thus increasing the probability that their campaigns will succeed.

\section{Proponents' Internal Social Capital and the Attraction of Early Contributions}

In the previous section, we maintain that early contributions reduce the uncertainty surrounding crowdfunding projects, thus increasing the probability that a crowdfunding campaign will succeed. However, in the very first days of a campaign, early backers can neither judge a project by observing prior contributions nor benefit from information conveyed by prior backers. Therefore, what determines the attraction of early contributions remains a significant issue. Previous studies on crowdfunding stress the role of social capital, defined as "the sum of the actual and potential resources embedded within, available through, and derived from the social contacts of an individual or an organization" (Nahapiet \& Ghoshal, 1998, p. 243).

Agrawal et al. (2011) use data from Sellaband - a crowdfunding platform specialized in music - and show that most early backers are located in the same geographical area of the proponent. These are likely to be people with whom proponents have social contacts, established through real-life interactions, including close friends and family members. In a similar vein, using evidence from case studies on projects posted on three crowdfunding platforms (Sellaband, Trampoline, and Kapipal), Ordanini et al. (2011) document that in the initial phase of a crowdfunding project (which the authors call friend-funding phase), contributions are primarily made by the close friends of proponents, who join the platform only to support their friends initiative. It is worth noting that direct social contacts can be mediated by online social networks. For example, Mollick (2014) finds that a proponent's number of Facebook friends is positively associated with the amount of capital raised in a crowdfunding campaign, although not having a Facebook account is better than having few Facebook friends. In general, the evidence provided by the nascent crowdfunding literature is consistent with previous studies in entrepreneurial finance that have long emphasized how social contacts help overcome the information asymmetries between entrepreneurs and investors that make it difficult to obtain seed finance (see, e.g., Shane, 2009; Shane \& Cable, 2002).

This paper contributes to the current debate on the role of social capital in crowdfunding and more generally in seed financing by acknowledging that in addition to

3. https://www.kickstarter.com/projects/phorce/phorce-the-worlds-first-smart-bag?ref=live, accessed March $31,2014$. 
relying on social contacts established outside a crowdfunding platform (e.g., family and friends, Facebook or LinkedIn contacts), a project proponent may develop an additional stock of social capital within that platform by establishing relationships with other proponents and backers. We call this type of social capital internal and hold it separate from the external social capital composed of family and friends (with or without the mediation of online social networks). Unlike external social capital, internal social capital relates to social contacts developed from within a collective. Prior works have identified collectives in firms (Leana \& Van Buren, 1999), groups of firms forming a strategic alliance (Kale, Singh, \& Perlmutter, 1990), and local communities (Westlund, Rutten, \& Boekema, 2010). In our case, the collective is the crowdfunding platform, where computer-mediated interactions occur among members of the virtual community composed of proponents and backers of projects (Faraj \& Johnson, 2011). These interactions entail behavior that is specific to crowdfunding communities and includes giving attention, money, feedback, and visibility to the projects of other members of the community.

To the best of our knowledge, neither the literature on crowdfunding nor the literature on social capital in seed financing has underpinned the distinction between external and internal social capital. Internal social capital is proven to influence the performance of individuals and organizations (Leana \& Pil, 2006), their innovative capabilities (Maurer, Bartsch, \& Ebers, 2011), and their ability to complete complex projects (Han \& Anat, 2013). With respect to internal social capital developed within online communities, Lin, Prabhala, and Viswanathan (2013) find that borrowers that have online friends within Prosper.com (a platform for peer-to-peer lending) are more likely to be funded, receive money at lower interest rates, and have a lower probability of ex-post default. Expanding on that evidence, we argue that independent of proponents' external social capital, proponents' internal social capital developed before launching a project is a powerful engine for the attraction of early contributions, thereby positively influencing the success of the crowdfunding campaign. Proponents' social contacts within a platform (hereafter: internal social contacts) are useful because they spread information beyond the circle of one's own acquaintances and more importantly, because they trigger reciprocity through a feeling of perceived obligation (Coleman, 1990). Reciprocity is a well-known hallmark of internal social capital (Tsai \& Ghoshal, 1998) and in the case of crowdfunding has two main facets. First, internal social contacts that have received money from a certain proponent feel obliged to help by giving back. This obligation is named specific reciprocity and is sustained by feelings such as "I help you as you have helped me in the past" (Faraj \& Johnson, 2011; Putnam, 1995). Second, a proponent benefits from a norm of generalized reciprocity within the online community built around the platform when he or she has backed many projects in the past (Faraj \& Johnson, 2011; Portes, 1998). Norms of generalized reciprocity have been documented in the open source community (Metiu \& Kogut, 2001) and in other online communities (Wasko \& Faraj, 2005). Members of a crowdfunding platform may feel obliged to show their support to other projects because they are grateful to have received support in the past or because they expect to need support in the future. An important ingredient of generalized reciprocity is that one's reciprocating behavior is visible to others in the community, allowing one to establish a reputation of giver (Bolino, Turnley, \& Blooddgood, 2002). In this respect, Kickstarter displays the number of projects that proponents have supported in their public profile, linked to their project pages, so that one can learn whether those who ask for support today have been generous members of the community in the past. We conjecture that this information makes early backers more willing to pledge money in favor of proponents that have behaved as good members of the crowdfunding community, compared with proponents who have not. 
Finally, from the observation of the platform activities, it appears evident that project proponents share a sense of mutual identification (Nahapiet \& Ghoshal, 1998). For example, some Kickstarter proponents have established a rule called "KickingItForward" which suggests that proponents who have received support in Kickstarter reinvest systematically $5 \%$ of their eventual profits to support other proponents' projects. ${ }^{4}$

In sum, the internal social capital that proponents have developed within the crowdfunding community is a powerful engine for attracting early support, beyond the effect attributable to their external social capital. In this paper, we posit that early support for a project is indicated both by the number of backers (early backers) and the share of target capital collected (early capital) in the initial days of a campaign. The two measures are related but quite distinct because backers can pledge either small or large amounts and because different projects have different-sized budgets. Hypotheses 1a and $1 \mathrm{~b}$ are therefore formulated as follows:

Hypothesis 1a: Project proponents' internal social capital has a positive effect on the number of early backers of crowdfunding campaigns.

Hypothesis 1b: Project proponents' internal social capital has a positive effect on the amount of early capital raised by crowdfunding campaigns.

Once an adequate number of early backers and/or a sufficient amount of early capital have been attracted, the reinforcing mechanisms of observational learning, word-of-mouth, and uncertainty reduction through extensive feedback begin to operate and contribute to accelerate a crowdfunding campaign's success. We argue that proponents' internal social capital is critical to attract backers and raise capital in the initial days of a campaign when those self-reinforcing mechanisms are not yet operating. Once early contributions have been attracted and the "success-breeds-success" mechanism is set in motion, the effect of internal social capital fades. In brief, we expect the positive effect of internal social capital on the success of crowdfunding campaigns to be mediated by early contributions. Thus, we formulate hypothesis 2 :

Hypothesis 2: The number of early backers and the amount of early capital mediate the positive effect of project proponents' internal social capital on the success of crowdfunding campaigns.

\section{Study Context and Data}

\section{Crowdfunding at Kickstarter}

In this paper, we use data about reward-based crowdfunding from Kickstarter, a United States-based platform that operates worldwide and is currently the largest existing crowdfunding provider in terms of money raised and projects financed. Data from Kickstarter have also been used in other works (e.g., Kuppuswamy \& Bayus, 2013; Mollick, 2014), enabling comparisons across studies.

Kickstarter hosts crowdfunding campaigns in a large number of categories, including art, comics, dance, design, fashion, film, food, games, music, photography, publishing, technology, and theater. Its website was launched in the second quarter of 2009. By the end of March 2014, it had hosted 139,564 projects and raised approximately 1 billion dollars in

4. http://kickingitforward.org/, accessed March 31, 2014. 
capital pledges. Kickstarter employs an "all-or-nothing," "reward-based" crowdfunding model. "All or nothing" means that if the money pledged to a project by the day a campaign closes is equal to or greater than the target amount, then the money is cashed in by the proponent; otherwise, the campaign is unsuccessful, and all pledges are voided. "Rewardbased" means that backers pledge money in exchange for a reward chosen from various rewards offered by a project's proponents. There may be different types of rewards, for example, a finished product, a gadget, and participation in an event such as the first screening of a film. In principle, rewards may be priced between $\$ 1$ and $\$ 10,000$. In practice, most rewards are priced between $\$ 1$ and $\$ 500$. Rewards cannot be a share of profits, an interest rate, or anything else that might configure the transaction as involving an offer of equity or a loan. Backers may opt to decline a reward, but in general, the platform does not allow the collection of money for charitable or philanthropic initiatives.

Kickstarter offers a window into projects open for crowdfunding at the specific moment that a user approaches its website. The projects may be browsed by category. When clicking on a project name, the user is taken to a page containing a description of that project. Usually, the description is written and complemented by pictures or videos. The other immediately available information is the real-time amount of capital raised, the percent of target capital raised, the number of people who have pledged, and how many days remain before the closure of the campaign. Proponents can provide information about themselves in a biography section, which also traces their prior activities as backers or proponents. Backers' identities are not visible during a campaign.

\section{Sample and Variables}

We prepared a sample composed of projects in four categories: design, technology, film and video, and video games. Kickstarter's categorization of projects has constantly changed over time, and summary figures were not available at the time of data collection. In general, the platform hosts projects with technological, artistic, and creative content. Accordingly, we selected four categories_-among several possible — that provided a relatively comprehensive representation of available project types: technology and video games account for projects having a technological content, film and videos account for projects with an artistic content, and design accounts for projects with a creative content. The sample is not necessarily representative of the overall population of Kickstarter projects, a fact that we keep in mind when discussing our results. The data collection included all projects posted since October 20, 2012 and closed by January 10, 2013 in the categories of design, technology, and video games (the latter is a subset of the broader category of games, which also includes board games). The collection of projects in the category of film and videos, which is comparatively larger in terms of the number of projects posted, started later and was performed as a random choice of projects posted after November 20, 2012 and closed by January 10, 2013. In total, we obtained an initial sample of 669 projects.

We coded three sets of information about each project. The first set of information related to the project characteristics: project category, duration of the campaign (Duration), target capital in dollars (Ln_Target_Capital), number of visuals (images and videos) in the project description (Ln_Visuals), and number of links to external websites with further information about the project (More_Information).

We also collected information about the type of rewards offered. Nearly all projects offer a product presale, but considerable variance exists with respect to additional types of rewards. We coded the following (non mutually exclusive) cases separately: (1) projects offering customized products or services, such as a design lamp with a picture of the backer's 
choice (D_Customized); (2) projects offering what we call "ego-boosting" types of rewards (D_Ego_Boosting), such as including the backer's name in a public URL or credit list; and (3) projects offering "community-belonging" types of rewards ( $D_{-}$ Community_Belonging). The latter type of reward involves events that provide opportunities for social interaction (e.g., an invitation to a development workshop or to a launch party) and the offering symbolic objects (e.g., a branded outfit) meant to display support for a project.

A second set of information related to proponents. We coded internal social capital as represented by the number of Kickstarter projects that a proponent had backed at the time of launching her own crowdfunding campaign (Internal_Social_Capital). This represents the degree to which the proponent has been supportive of Kickstarter projects and therefore has established social contacts with peers inside the community. This information was coded at the time the crowdfunding campaign began. We also recorded the number of connections that each individual proponent had on her LinkedIn profile (External_Linkedin). LinkedIn connections represent individual proponents' professional social contacts prior to launching their campaigns. LinkedIn connections are not immediately available on the Kickstarter platform (unlike Facebook connections). A search of LinkedIn was conducted based on the name, address, and profession of project proponents, when available. ${ }^{5}$ We tend to prefer a measure of professional social capital (such as that offered by LinkedIn) to a measure of social capital based on friendship (such as that offered by Facebook) for two reasons. First, Kickstarter transactions are of a commercial nature. Second, the number of LinkedIn connections more closely mirrors the construction of the internal social capital variable, enabling us to compare the effect of peers/ colleagues internal and external to the crowdfunding platform. However, we show that the results are indifferent to the use of LinkedIn, Facebook, or both in the robustness checks. Finally, we coded whether the proponent was located in the United States (D_USA) and whether the proponent was an individual or a company and in the case of an individual proponent, gender (D_Individual_Male, D_Individual_Female).

A third set of information related to the crowdfunding campaign and its outcome. We monitored projects throughout their campaigns. For the purpose of this analysis, we are particularly interested in the early days of a campaign. We characterized as early those activities occurring within an observation window fixed conventionally between day 1 (campaign launch) and the day at which the campaign has passed one sixth of its total period. For the vast majority of crowdfunding campaigns, which span 30 days, this observation window covers the first 5 days. For the shortest campaigns ( 7 days), the window is 2 days, whereas it is 10 days for the longest campaigns ( 60 days). At the end of this observation window, we coded the number of backers that had supported the project (Ln_Early_Backers) and the percentage of target capital pledged (Early_Capital). The same information was collected at the time of closure, and we coded a dummy

5. This measure was collected after the closure of each project. Due to the design of our collection method, we cannot exclude the existence of biases caused by the potential endogeneity of the measure-namely, that proponents' LinkedIn connections increase as consequences of engaging in a project or of the success of a crowdfunding campaign. To assess the severity of this potential bias, we collected a random sample of 51 project proponents with a LinkedIn account and coded the number of connections at the dates of a project's launch and closure. On average, project proponents had 177.0 contacts at the time of launch (standard deviation $=179.1$ ) and 194.3 at the time of closure (standard deviation $=183.4)$. The difference between these two values was found to be only weakly significant (at $10 \%$ ) through a paired $t$-test. However, the correlation between the number of LinkedIn connections of project proponents at the times of launch and closure of a crowdfunding campaign was very high (.93) and significant at 1\%. Moreover, the difference between the two values was not influenced by the success or failure of the campaign, with the correlation being -.06 and not statistically significant at conventional confidence levels. 
variable for successful campaigns equal to one if the project had met the target capital at the closure of the campaign (D_Success).

The summary statistics and definitions of the variables are shown in Table 1.

\section{Descriptive Statistics}

Table 2 provides preliminary descriptive statistics by project category. The first three rows of the table summarize campaign outcomes by project category. Our sample design allowed us to investigate not only whether a project met the target capital by closure (i.e., whether the crowdfunding campaign was successful), but also whether it was cancelled before the day of closure (i.e., Quit). The platform is silent on the topic of quitting. Of the campaigns included in our data, more than one in three were successful at closure $(37.4 \%)$, more than one in two were unsuccessful $(51.6 \%)$, and 74 projects out of 669 were cancelled $(11.1 \%)$. Quitting occurs more frequently as the deadline approaches: only 19 projects out of 74 quit during the first half of their campaigns. Not surprisingly, none of the canceled projects appeared to be performing well before quitting. Therefore, although in principle quitting may occur for many different reasons, in practice, we suspect that many use quitting as a discreet alternative to failing. Success is not evenly distributed by project category (the null hypothesis that successful campaigns are evenly distributed across the four project categories is rejected at conventional confidence levels, $\chi^{2}[3]=28.63$ ). The proportion of successful campaigns is higher than average in design and considerably lower than average in video games. We keep this in mind when modeling the likelihood of success.

Table 2 also reports the mean and standard deviation for several project characteristics, useful for understanding the general features of Kickstarter's crowdfunding campaigns. On average, the total amount of capital that a project seeks to raise is limited $(\$ 31,199)$, and there is considerable variance across projects, with approximately one fourth of projects seeking less than $\$ 4,000$ and approximately one tenth seeking to raise $\$ 100,000$ or more. On average, video game projects tend to ask for more capital $(\$ 51,782)$ than do other types of projects. For the 595 campaigns (i.e., 669 minus the 74 quitted projects) that continued through closure, we computed the mean and standard deviation of the percentage of target capital pledged at closure, which is the total pledges raised by the end of the last day divided by the target capital (note that funding is not capped at the target and thus, campaigns may raise more than $100 \%$ of the amount requested). This variable shows a peculiar distribution. A few projects $(2.3 \%)$ receive no pledges at all. More typically, unsuccessful campaigns raise $20 \%$ or less of the target capital. In total, unsuccessful campaigns represent $45.0 \%$ of all campaigns active at closure. Fewer than one in 10 projects raise between $21 \%$ and $40 \%$ (7.0\%); a few raise between $41 \%$ and $60 \%(4.2 \%)$ and even fewer raise between $61 \%$ and $80 \%(1.3 \%)$. Only two projects $(.3 \%)$ raise between $80 \%$ and $100 \%$ of the target capital. Conversely, a sizable proportion of projects $(16.0 \%)$ receive pledges of between $100 \%$ and $120 \%$ of the target capital, another $6.2 \%$ receive pledges of between $120 \%$ and $140 \%$, and another long tail of projects that exhibit higher percentages follows. In sum, the distribution of pledged capital follows a bimodal pattern, whose modes are approximately $0 \%$ and $100 \% .^{6}$ The bimodality coefficient is equal to .82. The Hartigan Dip statistic is equal to .048 , significant at 1\% (Hartigan \& Hartigan, 1985). There is considerably less variation

6. See Figure 1 in the Online Appendix available at the following URL: http://www.dig.polimi.it/uploads/ media/CFRL_Online_Appendix_01.pdf, and upon request to the corresponding author. 


\section{Variable Description and Summary Statistics}

\begin{tabular}{|c|c|c|c|c|c|c|}
\hline & Observations & Mean & $\begin{array}{l}\text { Standard } \\
\text { deviation }\end{array}$ & Min & Max & Variable description \\
\hline D_Success & 502 & .155 & .363 & 0 & 1 & $\begin{array}{l}\text { Dummy }=1 \text { if end pledges are greater } \\
\text { than or equal to target capital; } 0 \\
\text { otherwise }\end{array}$ \\
\hline Ln_Early_Backers & 502 & 2.358 & 1.489 & 0 & 7.397 & $\begin{array}{l}\text { Ln(Number of backers pledging at one } \\
\text { sixth of campaign duration }+1)\end{array}$ \\
\hline Early_Capital & 502 & .064 & .073 & 0 & .288 & $\begin{array}{l}\text { Total pledges at one sixth of campaign } \\
\text { divided by target capital }\end{array}$ \\
\hline Internal_Social_Capital & 502 & 1.669 & 3.389 & 0 & 29 & $\begin{array}{l}\text { Number of projects that the proponent } \\
\text { had backed at the time of campaign } \\
\text { launch }\end{array}$ \\
\hline Sq_Internal_Social_Cap & 502 & 14.251 & 56.825 & 0 & 841 & $\begin{array}{l}\text { Number of projects that the proponent } \\
\text { had backed at the time of campaign } \\
\text { launch }^{2}\end{array}$ \\
\hline External_Linkedin & 502 & .487 & 1.210 & 0 & 5.01 & $\begin{array}{l}\text { Number of LinkedIn connections/100 if } \\
\text { proponent is an individual; } 0 \\
\text { otherwise }\end{array}$ \\
\hline D_Individual_Male & 502 & .450 & .498 & 0 & 1 & $\begin{array}{l}\text { Dummy }=1 \text { if proponent is an } \\
\text { individual and gender is male }\end{array}$ \\
\hline D_Individual_Female & 502 & .046 & .209 & 0 & 1 & $\begin{array}{l}\text { Dummy }=1 \text { if proponent is an } \\
\text { individual and gender is female }\end{array}$ \\
\hline Duration & 502 & 30.374 & 7.900 & 7 & 60 & Duration of campaign in days \\
\hline D_Ego_Boosting & 502 & .155 & .363 & 0 & 1 & $\begin{array}{l}\text { Dummy }=1 \text { if the project has at least } \\
\text { one reward that entails crediting the } \\
\text { backers publicly }\end{array}$ \\
\hline D_Community_Belonging & 502 & .574 & .495 & 0 & 1 & $\begin{array}{l}\text { Dummy }=1 \text { if the project has at least } \\
\text { one reward that fosters feelings of } \\
\text { community belongings }\end{array}$ \\
\hline D_Customized & 502 & .420 & .494 & 0 & 1 & $\begin{array}{l}\text { Dummy }=1 \text { if the project has at least } \\
\text { one reward that offers a customized } \\
\text { product or service }\end{array}$ \\
\hline Ln_Visuals & 502 & 2.007 & .806 & .693 & 4.317 & $\begin{array}{l}\text { Ln(Number of pictures and videos in } \\
\text { project description }+1 \text { ) }\end{array}$ \\
\hline More_Information & 502 & 2.000 & 1.582 & 0 & 13 & $\begin{array}{l}\text { Number of links external to Kickstarter } \\
\text { provided in project description }\end{array}$ \\
\hline Ln_Target_Capital & 502 & 2.408 & 1.700 & -3.468 & 7.021 & Ln(Target capital in thousand dollars) \\
\hline D_USA & 502 & .765 & .424 & 0 & 1 & $\begin{array}{l}\text { Dummy }=1 \text { if project location is in the } \\
\text { United States; } 0 \text { otherwise }\end{array}$ \\
\hline D_Design & 502 & .323 & .468 & 0 & 1 & $\begin{array}{l}\text { Dummy }=1 \text { if project category is } \\
\text { "design"; } 0 \text { otherwise }\end{array}$ \\
\hline D_Film_Video & 502 & .137 & .345 & 0 & 1 & $\begin{array}{l}\text { Dummy }=1 \text { if project category is "film } \\
\text { and video"; } 0 \text { otherwise }\end{array}$ \\
\hline D_Technology & 502 & .145 & .353 & 0 & 1 & $\begin{array}{l}\text { Dummy }=1 \text { if project category is } \\
\text { "technology"; } 0 \text { otherwise }\end{array}$ \\
\hline D_Videogame & 502 & .394 & .489 & 0 & 1 & $\begin{array}{l}\text { Dummy }=1 \text { if project category is "video } \\
\text { game"; } 0 \text { otherwise }\end{array}$ \\
\hline
\end{tabular}

Descriptive statistics relate to the 502 projects out of the 669 sample projects that at one sixth of the crowdfunding campaign had collected a share of target capital lower than $28.8 \%$, the value corresponding to the 75 th percentile of the distribution, and were therefore considered as being at high risk of failure. 


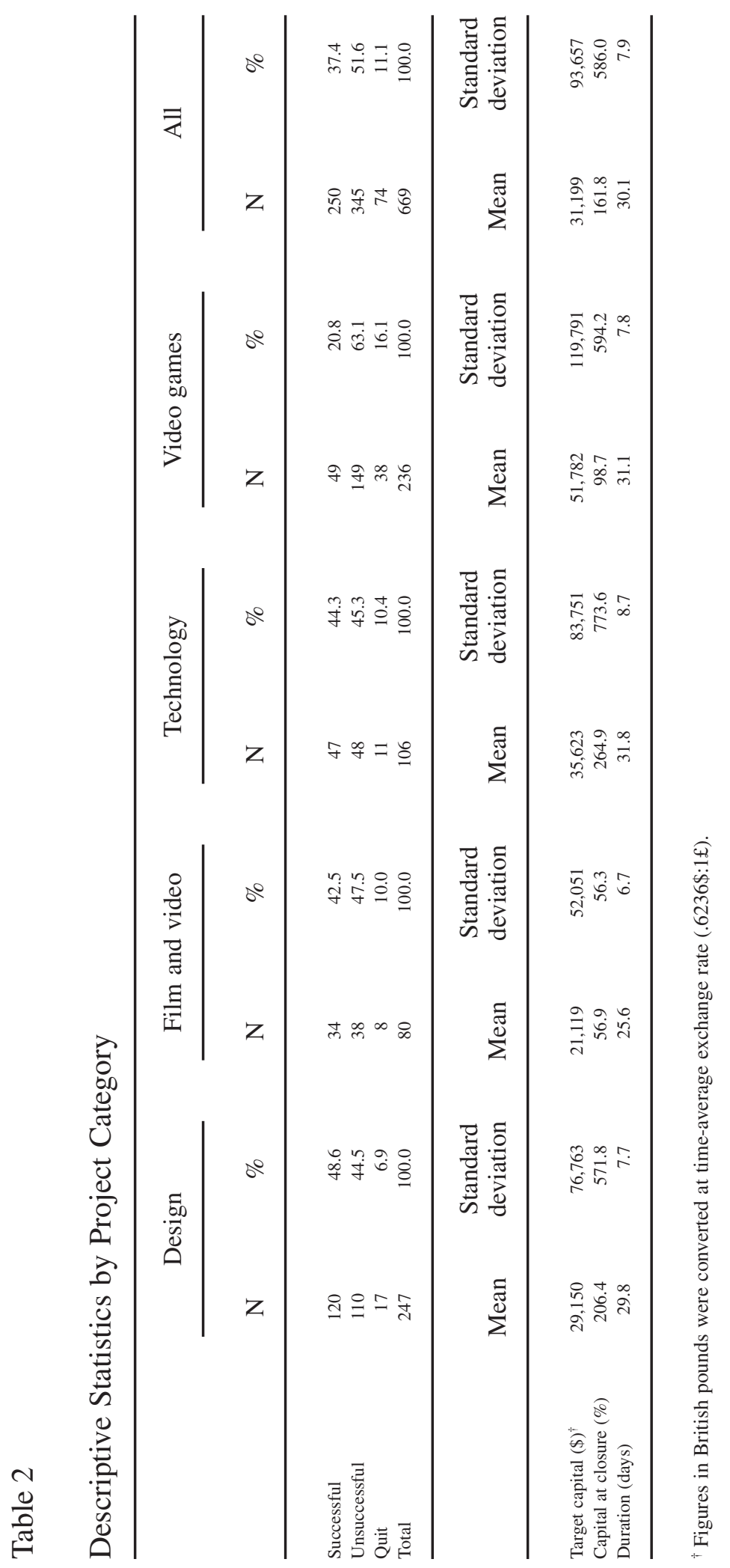


in the duration of crowdfunding campaigns. The typical duration of a funding campaign is 1 month: approximately half last 30 or 31 days. One quarter is shorter in duration, and the remaining one quarter lasts between 32 and 60 days, with 40, 45, and 60 days being slightly more common periods.

\section{Results}

\section{The Relation Between Early Contributions and the Success of Crowdfunding Campaigns}

In this section, we provide quantitative evidence that early support for a project is an important antecedent of the success of a crowdfunding campaign. Given that the percentage of target capital raised by closure follows a bimodal distribution, we choose to summarize the dependent variable as a dummy, taking the value 1 if the campaign was successful (pledges covered 100\% of the target capital or more) and 0 otherwise (pledges covered less than the target capital). The projects that the proponents quit are coded as 0 . In accordance with this choice, we model the probability of success of a crowdfunding campaign using a robust probit estimate. After one sixth of the campaign period has elapsed, the median project has collected $7 \%$ of its target capital, but there is a right tail of projects that have already raised a sizable amount of capital, which in some cases amount to sums equal to or even greater than the target capital. To manage the potential interference caused by a success-breeds-success pattern that may manifest prior to our observation window, we restricted the estimates to the subsample of campaigns at high risk of succeeding or failing at the time when we measured the early contributions. We took a conservative approach in censoring and removed from the restricted sample not only the projects that had already covered the entire target capital at one sixth of the campaign period, but also all of the other projects in the top quartile of the distribution of the share of target capital covered. The 502 remaining projects had collected from $0 \%$ to a maximum of $28.8 \%$ of the target capital by one sixth of the project campaign and were then treated as being at high risk of failure. Selection into censoring is discussed in the robustness checks.

Our explanatory variables are the logarithm of the number of backers that make a pledge by one sixth of the campaign and the percent of target capital raised during the same days. We controlled for proponent characteristics and project characteristics, including types of reward and four dummy variables of project categories. The correlation matrix and the variance inflation factors (VIFs) are reported in Table 3. The average VIF was 1.64 (below the conventional threshold of 6), and the maximum VIF was 3.10 (below the conventional threshold of 10, McDonald \& Moffit, 1980). Thus, we conclude that multicollinearity does not appear to be a problem in our estimates.

The results of model estimation are reported in Table 4. As expected, early contributions are closely associated with the final success of a crowdfunding campaign. Quite interestingly, both the number of early backers (Ln_Early_Backers) and the percent of target capital pledged early in the project campaign (Early_Capital) are positive predictors of success (significant at 1\%). The effects of these variables are of considerable economic magnitude. With all continuous variables at their mean value and dummy variables at their median value, a one-standard deviation increase of Ln_Early_Backers leads to an $83 \%$ increase (from $9.3 \%$ to $17.1 \%$ ) in the likelihood of a project being successful. The corresponding increase caused by Early_Capital is $+133 \%$ (from $9.3 \%$ to $21.8 \%)$. 


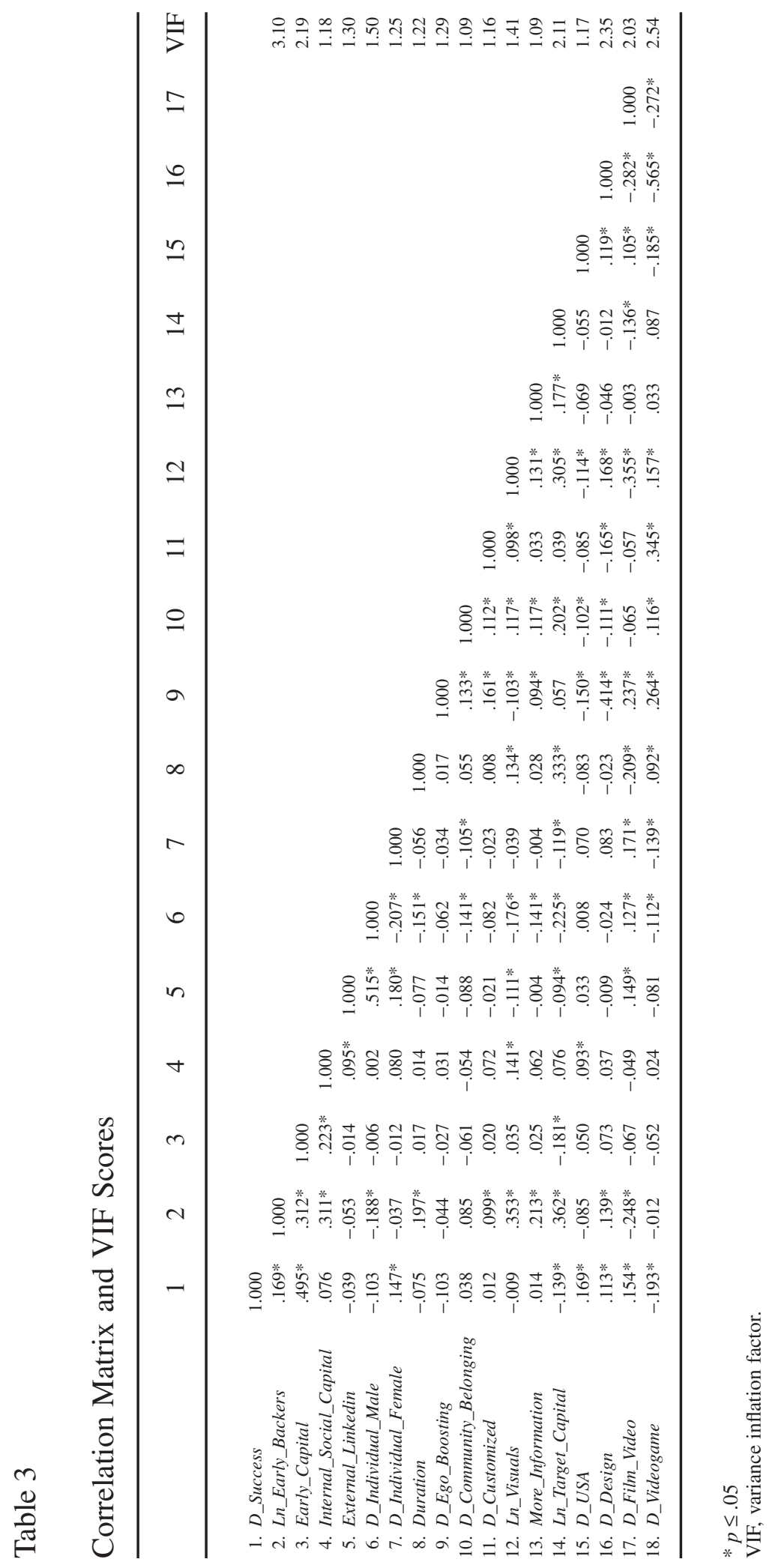


Table 4

Success of Crowdfunding Campaigns: Probit Model

\begin{tabular}{|c|c|}
\hline & Model I \\
\hline Ln_Early_Backers & $\begin{array}{l}.248^{* * * *} \\
(.114)\end{array}$ \\
\hline Early_Capital & $\begin{array}{l}7.364 * * * \\
(1.486)\end{array}$ \\
\hline D_Individual_Male & $\begin{array}{l}-.499 * * * \\
(.191)\end{array}$ \\
\hline D_Individual_Female & $\begin{array}{c}.139 \\
(.339)\end{array}$ \\
\hline Duration & $\begin{array}{l}-.000 \\
(.012)\end{array}$ \\
\hline D_Ego_Boosting & $\begin{array}{c}-.361^{*} \\
(.208)\end{array}$ \\
\hline D_Community_Belonging & $\begin{array}{l}.577 * * * \\
(.178)\end{array}$ \\
\hline D_Customized & $\begin{array}{l}.100 \\
(.177)\end{array}$ \\
\hline Ln_Visuals & $\begin{array}{l}.110 \\
(.135)\end{array}$ \\
\hline More_Information & $\begin{array}{c}-.022 \\
(.051)\end{array}$ \\
\hline D_USA & $\begin{array}{l}.791 * * \\
(.347)\end{array}$ \\
\hline Ln_Target_Capital & $\begin{array}{l}-.327 * * * \\
(.094)\end{array}$ \\
\hline Project category dummies & Yes \\
\hline Constant & $\begin{array}{c}-2.551 * * * \\
(.674)\end{array}$ \\
\hline Observations & 502 \\
\hline Maximum VIF & 2.97 \\
\hline Mean VIF & 1.66 \\
\hline McFadden's pseudo $\mathrm{R}^{2}$ & .381 \\
\hline
\end{tabular}

With respect to control variables, in accordance with prior evidence (Mollick, 2014), probability of success is negatively related to the target capital $(p<.01)$. Campaign duration does not appear to be associated with success. United States-based projects are $6.4 \%$ more likely to succeed $(p<.05)$. Neither the number of external links (More_Information) nor (the log of) the number of images and videos (Ln_Visuals), which may be regarded as proxies of project quality (see again Mollick, 2014), exhibit significant coefficients. We infer that if these variables have any effects on the likelihood of project success (as suggested by previous studies), in our sample, these effects are fully mediated by early contributions. We return to this issue later in the paper. With respect to types of rewards, a reward that fosters a sense of community belonging (D_Community_Belonging) yields a 6.0\% increase in likelihood of success (significant at $1 \%)$. Conversely, offering public recognition of support (D_Ego_Boosting) is associated with a $4.1 \%$, on average, decrease in likelihood of success (significant at $10 \%$ ). With respect to proponent characteristics, individual project proponents who are male 
are less likely to succeed than companies (baseline) or females (significant at $1 \%$ ). Project category dummies are jointly significant at $1 \%\left(\chi^{2}[3]=24.48\right)$, in line with the prior descriptive evidence.

\section{Determinants of the Attraction of Early Contributions}

Having found confirmation in our data that the number of backers and the percentage of target capital raised as early as at one sixth of a project's duration are positive predictors of success, in this section we conduct a deeper exploration of the factors associated with receiving early support, whether in the form of early backers or early pledges. We maintain that the internal social capital built by backing other projects within the Kickstarter community is a positive predictor of both the number of early backers (hypothesis 1a) and the early capital pledged (hypothesis 1b). Because the dependent variables (Ln_Early_Backers and Early_Capital) take only positive values and because there are several projects that did not receive any support in their early days (51 projects received zero pledges), we model our outcome variables using a Tobit model, censored at 0 . The results of the estimates, based on the restricted sample of 502 projects at high risk of failure after one sixth of the crowdfunding campaign, are reported in Table 5. In model I, the dependent variable is the log of early contributors (Ln_Early_Backers); in model II, it is the percentage of the target capital raised early (Early_Capital).

In both models, the coefficients of the Internal_Social_Capital variable are positive (significant at $1 \%$ ), providing support to hypothesis $1 \mathrm{a}$ and hypothesis $1 \mathrm{~b}$, respectively. To assess the economic magnitude of these effects, we set all continuous variables at their mean values and all dummy variables at their median value, and calculated the increase in the estimated value of early capital and backers engendered by a one-standard deviation increase in the independent variable (McDonald \& Moffit, 1980). The results indicate that a one-standard deviation increase in Internal_Social_Capital is associated with a predicted increase of 5.1 early backers (from 13.8 to 18.9 ), which equals a $37.1 \%$ increase from the initial value. The corresponding increase of Early_Capital is equal to 1.2 percentage points (from $8.6 \%$ to $9.8 \%$ ), which is only $13.4 \%$ of the initial value. We conclude that internal social capital is more strongly associated with a boost in the number of early backers than with early capital.

The coefficient of the external social capital variable, which we included as a control (External_Linkedin), is a positive predictor of Ln_Early_Backers (significant at 1\%) and Early_Capital (significant at 5\%). The magnitude of the effect of this variable is weaker than that of internal social capital. With all remaining variables at their mean or median values, a one-standard deviation increase in the number of LinkedIn connections leads to an increase of 2.4 early backers, corresponding to a $12.5 \%$ increase from the initial value of the dependent variable. The estimated increase in Early_Capital is even smaller: .8 percentage points, corresponding to $7.9 \%$ of the initial value.

With respect to the other control variables, we find that larger projects (i.e., projects with a larger amount of target capital) have a tendency to attract more early backers but raise a smaller share of the target capital by one sixth of the campaign: Ln_Target_Capital has a positive coefficient in model I and a negative one in model II, both significant at $1 \%$. More visuals in project description are associated with more early contributions in both models (significant at 1\%). The coefficient of More_Information, which reflects links to other websites, is also positive but is significant (at 1\%) only in the Early_Capital model. These results are in line with previous work (Mollick, 2014) and show overall that project quality is an important predictor of the success of crowdfunding campaigns, although our findings suggest that this effect is mediated by 
Table 5

Antecedents of Early Contributions: Tobit Estimates

\begin{tabular}{|c|c|c|c|c|}
\hline & \multicolumn{2}{|c|}{ Ln_Early_Backers } & \multicolumn{2}{|c|}{ Early_Capital } \\
\hline & Model I & Model I-bis & Model II & Model II-bis \\
\hline Internal_Social_Capital & $\begin{array}{l}.094 * * * \\
(.017)\end{array}$ & $\begin{array}{l}.156 * * * \\
(.030)\end{array}$ & $\begin{array}{l}.004 * * * \\
(.001)\end{array}$ & $\begin{array}{l}.007 * * * \\
(.002)\end{array}$ \\
\hline Sq_Internal_Social_Cap & & $\begin{array}{l}-.004 * * * \\
(.001)\end{array}$ & & $\begin{array}{l}-.0002 * * * \\
(.0001)\end{array}$ \\
\hline External_Linkedin & $\begin{array}{l}.141 * * * \\
(.045)\end{array}$ & $\begin{array}{l}.135^{* * * *} \\
(.046)\end{array}$ & $\begin{array}{l}.007 * * \\
(.003)\end{array}$ & $\begin{array}{l}.007 * * \\
(.003)\end{array}$ \\
\hline D_Individual_Male & $\begin{array}{l}-.552^{* * * *} \\
(.136)\end{array}$ & $\begin{array}{l}-.562 * * * \\
(.135)\end{array}$ & $\begin{array}{l}-.025 * * * \\
(.008)\end{array}$ & $\begin{array}{l}-.026^{* * * *} \\
(.008)\end{array}$ \\
\hline D_Individual_Female & $\begin{array}{l}-.161 \\
(.292)\end{array}$ & $\begin{array}{l}-.187 \\
(.294)\end{array}$ & $\begin{array}{l}-.003 \\
(.024)\end{array}$ & $\begin{array}{l}-.005 \\
(.024)\end{array}$ \\
\hline More_Information & $\begin{array}{l}.057 \\
(.037)\end{array}$ & $\begin{array}{l}.052 \\
(.038)\end{array}$ & $\begin{array}{l}.005 * * \\
(.002)\end{array}$ & $\begin{array}{l}.005^{* *} \\
(.002)\end{array}$ \\
\hline Ln_Visuals & $\begin{array}{l}.313 * * * \\
(.084)\end{array}$ & $\begin{array}{l}.298 * * * \\
(.084)\end{array}$ & $\begin{array}{l}.016^{* * * *} \\
(.005)\end{array}$ & $\begin{array}{l}.016 * * * \\
(.005)\end{array}$ \\
\hline$D \_U S A$ & $\begin{array}{l}-.394 * * * \\
(.148)\end{array}$ & $\begin{array}{l}-.400 * * * \\
(.147)\end{array}$ & $\begin{array}{l}.005 \\
(.007)\end{array}$ & $\begin{array}{l}.005 \\
(.007)\end{array}$ \\
\hline Ln_Target_Capital & $\begin{array}{l}.360 * * * \\
(.041)\end{array}$ & $\begin{array}{l}.359 * * * \\
(.041)\end{array}$ & $\begin{array}{l}-.008 * * * \\
(.002)\end{array}$ & $\begin{array}{l}-.008 * * * \\
(.002)\end{array}$ \\
\hline Project category dummies & Yes & Yes & Yes & Yes \\
\hline Constant & $\begin{array}{l}1.173 * * * \\
(.228)\end{array}$ & $\begin{array}{l}1.183^{* * *} \\
(.290)\end{array}$ & $\begin{array}{l}.043 * * * \\
(.016)\end{array}$ & $\begin{array}{l}.159 * * * \\
(.036)\end{array}$ \\
\hline Observations & 502 & 502 & 502 & 502 \\
\hline Uncensored & 451 & 451 & 451 & 451 \\
\hline Left-censored & 51 & 51 & 51 & 51 \\
\hline Sigma & $\begin{array}{l}1.245 \\
(.047)\end{array}$ & $\begin{array}{l}1.240 \\
(.046)\end{array}$ & $\begin{array}{l}.073 \\
(.003)\end{array}$ & $\begin{array}{c}.072 \\
(.003)\end{array}$ \\
\hline Maximum VIF & 2.34 & 4.66 & 2.34 & 4.66 \\
\hline Mean VIF & 1.48 & 2.02 & 1.48 & 2.02 \\
\hline
\end{tabular}

$* p<.10, * * p<.05, * * * p<.01$

Note: Robust standard error in parentheses.

VIF, variance inflation factor.

early contributions. On average, individual proponents who are male are less likely to receive support in terms of backers and capital than are females or companies. United States-based projects have a tendency to attract fewer early backers, whereas there are no significant effects of location on Early_Capital.

It is interesting to assess whether the effect of project proponents' internal social capital on early contributions becomes negative for high values of the Internal_Social_ Capital variable. The literature has extensively highlighted the risks of homologation and less divergent or creative thinking associated with too many internal social contacts (Burt, 2004; Portes, 1998), especially when confronting a fast-changing environment (Rowley, 2000). In the context of crowdfunding, this theory may predict that too many and too recursive interactions with the community internal to the crowdfunding platform may reduce proponents' exposure to new or divergent ideas and in the long run may undermine a proponent's ability to grasp the preferences and trends of a larger crowd. To test for this 
phenomenon, we inserted the squared term of Internal_Social_Capital (model I-bis and II-bis of Table 5) into the model specifications. In both models, the squared term exhibits a negative coefficient (significant at 1\%), although the inflection point is always in the $1 \%$ tail of the distribution (19.5 internal social capital links in model I-bis and just above 17 in model II-bis). Therefore, in our sample, the relation between project proponents' internal social capital and early contributions remains an increasing one, although at a decreasing rate, up to nearly the maximum of the variable scale.

One final comment relates to endogeneity, which is potentially caused by reverse causality or unobserved heterogeneity (or both). Reverse causality is not relevant in our context because we examine the behavior of anonymous backers who respond to the social connections that proponents might have developed before launching their projects. Furthermore, early contributions are largely motivated by generalized reciprocity, that is, they are given by individuals other than those whose projects have been backed by the focal proponent (i.e., individuals outside a project proponent's network of internal social contacts). In this regard, note that the average and maximum numbers of project proponents' internal social contacts are equal to 1.6 and 29; these values are considerably smaller than the average and maximum numbers of early backers (10.5 and 1,631). Therefore, there is no reason to presume that internal social contacts equal early backers or are entirely responsible for any early capital raised. Unobserved heterogeneity is a second concern. Although we cannot completely exclude the possibility that unobserved factors may drive both the building of internal social capital and the attraction of early contributions, our setting mitigates this concern. Typically, the unobservable heterogeneity argument applies to a situation in which the econometrician does not have access to data on variables (the unobservables) that are observed by the economic agents engaged in decision making. In our study, we have access to virtually all of the project information that potential backers see. Most of this information is included in our extensive list of controls. Therefore, if a variable is unobservable to us, it is also unobservable to potential backers (see Lin et al., 2013, for very similar arguments).

Finally, in hypothesis 2 we posited that internal social capital is a predictor of campaign success but that the number of early backers and the percentage of target capital raised early mediate this relationship. Once these factors are accounted for, the effect of internal social capital fades. To test this hypothesis, we estimated a mediation model. We first tested the relationship between the Internal_Social_Capital variable and the probability of success using a robust probit estimate. The results are reported in model I of Table 6 and confirm the existence of a positive relationship (significant at 5\%), net of a set of confounding factors. Interestingly, the coefficient of the External_Linkedin variable is not significant at conventional confidence levels. Therefore, according to our estimates after controlling for internal social capital and other confounding factors, project proponents' external social capital does not appear to be related to the likelihood of campaigns turning successful. We then reestimated the model by first including the variable Ln_Early_Backers alone (model II of Table 6) and then including the variable Early_Capital alone (model III of Table 6). In both cases, the coefficient of the Internal_Social_Capital variable is not significant at conventional confidence levels. Finally, when both mediating variables are included at the same time (model IV of Table 6), both of these coefficients remain positive and significant (as in the reference model reported in Table 4 discussed above), whereas the coefficient of the Internal_Social_Capital variable again is not significant. To assess the magnitude and statistical significance of the mediation effect, we resorted to the "product of coefficient approach" (MacKinnon \& Dwyer, 1993; Sobel, 1982). Because our final dependent variable is dichotomous, we used the Stata command binary_mediation (Ender, 2006), 
Table 6

Mediation Model: Probit Estimates

\begin{tabular}{|c|c|c|c|c|}
\hline & Model I & Model II & Model III & Model IV \\
\hline Internal_Social_Capital & $\begin{array}{l}.052 * * \\
(.022)\end{array}$ & $\begin{array}{l}.021 \\
(.024)\end{array}$ & $\begin{array}{l}.033 \\
(.026)\end{array}$ & $\begin{array}{l}.026 \\
(.026)\end{array}$ \\
\hline Ln_Early_Backers & & $\begin{array}{l}.662 * * * \\
(.096)\end{array}$ & & $\begin{array}{l}.235^{* * * *} \\
(.117)\end{array}$ \\
\hline Early_Capital & & & $\begin{array}{l}9.596 * * * \\
(1.114)\end{array}$ & $\begin{array}{l}7.571 * * * \\
(1.482)\end{array}$ \\
\hline External_Linkedin & $\begin{array}{l}.010 \\
(.080)\end{array}$ & $\begin{array}{l}-.050 \\
(.092)\end{array}$ & $\begin{array}{c}.075 \\
(.099)\end{array}$ & -.079 \\
\hline D_Individual_Male & $\begin{array}{l}-.618^{* * *} \\
(.180)\end{array}$ & $\begin{array}{l}-.400^{* *} \\
(.204)\end{array}$ & $\begin{array}{l}-.482 * * \\
(.192)\end{array}$ & $\begin{array}{l}-.430 * * \\
(.199)\end{array}$ \\
\hline D_Individual_Female & $\begin{array}{c}.074 \\
(.352)\end{array}$ & $\begin{array}{l}.173 \\
(.332)\end{array}$ & $\begin{array}{l}.253 \\
(.364)\end{array}$ & $\begin{array}{c}.244 \\
(.358)\end{array}$ \\
\hline Duration & $\begin{array}{c}-.002 \\
(.010)\end{array}$ & $\begin{array}{l}.006 \\
(.012)\end{array}$ & $\begin{array}{l}.004 \\
(.012)\end{array}$ & $\begin{array}{l}.001 \\
(.012)\end{array}$ \\
\hline D_Ego_Boosting & $\begin{array}{l}-.414 * * \\
(.175)\end{array}$ & $\begin{array}{l}-.392 * * \\
(.198)\end{array}$ & $\begin{array}{c}-.406^{*} \\
(.209)\end{array}$ & $\begin{array}{c}-.394 * \\
(.210)\end{array}$ \\
\hline D_Community_Belonging & $\begin{array}{l}.417^{* * * *} \\
(.159)\end{array}$ & $\begin{array}{l}.558 * * * \\
(.173)\end{array}$ & $\begin{array}{l}.621 * * * \\
(.182)\end{array}$ & $\begin{array}{l}.632 * * * \\
(.183)\end{array}$ \\
\hline D_Customized & $\begin{array}{l}.265^{*} \\
(.159)\end{array}$ & $\begin{array}{l}.179 \\
(.173)\end{array}$ & $\begin{array}{l}.123 \\
(.176)\end{array}$ & $\begin{array}{l}.116 \\
(.178)\end{array}$ \\
\hline Ln_Visuals & $\begin{array}{l}.158 \\
(.115)\end{array}$ & $\begin{array}{l}.115 \\
(.131)\end{array}$ & $\begin{array}{l}.073 \\
(.135)\end{array}$ & $\begin{array}{l}.075 \\
(.137)\end{array}$ \\
\hline More_Information & $\begin{array}{l}.025 \\
(.048)\end{array}$ & $\begin{array}{c}.010 \\
(.050)\end{array}$ & $\begin{array}{c}-.023 \\
(.051)\end{array}$ & $\begin{array}{c}-.019 \\
(.050)\end{array}$ \\
\hline D_USA & $\begin{array}{l}.699 * * * * \\
(.257)\end{array}$ & $\begin{array}{l}.984 * * * \\
(.320)\end{array}$ & $\begin{array}{c}.625 * \\
(.326)\end{array}$ & $\begin{array}{l}.743 * * \\
(.341)\end{array}$ \\
\hline Ln_Target_Capital & $\begin{array}{l}-.223^{* * *} \\
(.055)\end{array}$ & $\begin{array}{l}-.582 * * * \\
(.003)\end{array}$ & $\begin{array}{l}-.202 * * * \\
(.069)\end{array}$ & $\begin{array}{l}-.332 * * * \\
(.093)\end{array}$ \\
\hline Project category dummies & Yes & Yes & Yes & Yes \\
\hline Constant & $\begin{array}{c}-1.480 * * * \\
(.558)\end{array}$ & $\begin{array}{c}-2.519 * * * \\
(.678)\end{array}$ & $\begin{array}{c}-2.309 * * * \\
(.671)\end{array}$ & $\begin{array}{c}-2.519 * * * \\
(.678)\end{array}$ \\
\hline Observations & 502 & 502 & 502 & 502 \\
\hline Maximum VIF & 2.48 & 2.50 & 2.54 & 3.10 \\
\hline Mean VIF & 1.44 & 1.48 & 1.44 & 1.64 \\
\hline McFadden's Pseudo $\mathrm{R}^{2}$ & .190 & .326 & .378 & .386 \\
\hline
\end{tabular}

$* p<.10, * * p<.05, * * * p<.01$

Note: Dependent variable: D_Success. Robust standard error in parentheses.

VIF, variance inflation factor.

which allows for dichotomous dependent variables, multiple mediators, and computed confidence intervals by bootstrapping (with 2,000 replications). The total effect of Internal_Social_Capital on the likelihood of success was estimated at .189 (significant at $5 \%$ ). The estimated total indirect effect was equal to .123 (significant at 5\%), and was almost twice as large as the estimated direct effect, which was equal to .067 and was not significant at conventional confidence levels. The proportion of the total effect mediated by Ln_Early_Backers and Early_Capital is sizable (64.9). We conclude that in accordance with hypothesis 2 , the number of early backers and the percentage of the target capital pledged early fully mediate the relationship between internal social capital and the success of crowdfunding campaigns. 


\section{Robustness}

We performed several additional estimates to assess the robustness of the results to the choice of models or variables. A first control concerns the robustness of our findings reported in Table 4 to selection into the sample of observations no longer at risk of failure. To address this issue, we reestimated the model using a Heckman probit estimate. The results are consistent with those illustrated in the text, with the only exception being the control variable D_Ego_Boosting, whose coefficient remains negative but is no longer significant. A second control concerns the robustness of our findings to metrics used to measure external social capital. In the main estimates of Tables 5 and 6, we chose to use LinkedIn connections because LinkedIn reflects professional contacts. We then reestimated the model, showing that our estimates are robust both to replacing LinkedIn connections with Facebook friends and to including both variables at the same time. Facebook friends were measured at the time the focal project was launched and inserted into all models, following the specification used by Mollick (2014). As before, external social capital is positively associated with more early contributions and is not significantly associated with success. As a third and final robustness check, we show that our results are robust to controlling for the prior experience of project proponents. Prior experience was measured by the number of Kickstarter campaigns started by each individual proponent prior to launching the focal campaign. Note that this variable is not correlated to Internal_Social_Capital $($ corr. $=.067)$. All results are robust to the new specification. For reasons of brevity, robustness checks estimates are not reported here but are included in a separate document, which is available as an online appendix. ${ }^{7}$

\section{Conclusions}

In this paper, we examine the determinants of the success of crowdfunding campaigns by focusing on the internal social capital that proponents develop within a crowdfunding platform by supporting other community members' projects. Consistent with our hypotheses, our empirical estimates show that internal social capital is fundamental to attracting backers and raising capital in the early days of the campaign. In turn, these early contributions are closely associated with the likelihood of a project reaching its target capital, such that a head start fully mediates the effect of internal social capital on a campaign's success.

The paper advances the extant knowledge in several respects. First, it contributes to the nascent crowdfunding literature. Raising small amounts of money from many people is a practice as ancient as human society. However, Web 2.0 technologies have enabled proponents to broadcast their financing campaigns on the Internet, fueling the rapid diffusion of crowdfunding. In spite of this increasing popularity, academic research on crowdfunding is still at initial stage. The papers to examine the drivers of campaign success have observed that raising substantial amounts of capital in the early days of a campaign is a predictor of success (e.g., Agrawal et al., 2014) in a "success-breedssuccess," self-reinforcing pattern. In this paper, we take a further step in this direction by offering a comprehensive discussion of the reasons for that pattern (i.e., observational learning, word-of-mouth, and feedback from backers). Next, we quantitatively document this pattern by examining both the capital raised and the number of backers attracted in

7. The Online Appendix is available at the following URL: http://www.dig.polimi.it/uploads/media/ CFRL_Online_Appendix_01.pdf and upon request to the corresponding author. 
the early days of a campaign. We show that although both variables play a role, the amount of early capital raised has the strongest triggering effect on the self-reinforcing pattern. Moreover, we contribute to the debate on the role of social capital in crowdfunding, suggesting that crowdfunding communities are becoming loci of social interaction in which members are embedded in social relationships and develop internal social capital. These characteristics appear specific to crowdfunding compared to other sources of seed financing, and it is important to investigate whether they apply to other online funding contexts. Previous studies have shown the importance of the social capital that proponents possess outside of a crowdfunding community, including social capital from family and friends (Agrawal et al., 2011), and including social capital mediated by social networks (Mollick, 2014). Here, we shift the attention to a new source of social capital that seems to be emerging in crowdfunding platforms and is nurtured by supportive behaviors among proponents, mutual identification, and social norms of reciprocity. The positive effect of internal social capital on early contributions holds whether or not we control for the effect of external social capital, and the positive effect of internal social capital appears stronger in magnitude than that of external social capital.

Second, this paper contributes to the literature on social capital in seed financing. Specifically, scholars agree that entrepreneurs' social capital influences their ability to obtain seed capital. Most previous studies in this stream adhere to the view that information conveyed through social contacts between entrepreneurs and potential investors helps to reduce the information asymmetries that otherwise would hinder seed financing. In line with these arguments, Shane and colleagues (Shane \& Cable, 2002; Shane \& Stuart, 2002) show that direct and indirect social contacts between high-tech entrepreneurs and venture capitalists are positively associated with the provision of seed capital, but these effects are fully mediated by the reputation of the entrepreneurs. More generally, the social contacts of entrepreneurs act as signals (Spence, 2002) of ability and trustworthiness to uninformed external parties, again alleviating information asymmetries and favoring seed financing. Our study makes an original contribution to this debate by showing that not only personal social contacts, but also social contacts built within crowdfunding communities may be a vehicle to attract seed financing. Crowdfunding platforms appear to progressively develop into environments rich in social interactions, norms, and behaviors. These communities facilitate the generation and observation of additional (and possibly more impartial) information (Cheng et al., 2011) about entrepreneurs and the viability of their initiatives. Although the distinction between internal and external social capital is mainstream in the field of economics and management (Gedajlovic et al., 2013), it has gone rather underremarked in the ample literature on social capital in entrepreneurial finance. In our view, this hampers the understanding of the links between social capital and seed financing. Indeed, mainstream scholarly opinion is that external social capital matters in seed financing primarily because it reduces information asymmetries (see Kotha \& George, 2012, for an exception). Conversely, we argue that social contacts within communities may induce community members to finance entrepreneurial initiatives in compliance with social obligations, that is, norms of (specific and generalized) reciprocity (Portes, 1998). These social obligations are expressed by platform-specific behavior such as inspecting, funding, and giving feedback to the projects of other proponents. The fact that our results show that the effect of internal social capital in crowdfunding is even stronger than that of external social capital indicates that the influence of these norms of reciprocity is far from negligible and calls for future investigation.

This paper has some limitations that call for future research. First, we measured (internal and external) social capital using the aggregate number of project proponents' 
social contacts. Although measures like these are quite common in the social capital literature (see, e.g., Payne, Moore, Griffis, \& Autry, 2011, p. 498), they have weaknesses. Specifically, we cannot qualify the (economic and social) strength of each individual contact. In addition, we cannot see the network structure generated by a focal proponent's contacts nor the proponent's position within that network. The availability of such data could enable a more comprehensive understanding of the role of internal social capital in favoring the success of crowdfunding projects and of the relative importance of specific versus generalized reciprocity. Second, the social capital literature has also highlighted the downsides of social connections. For example, too much social cohesion may lead to homologation and harm creativity (Burt, 2004; Portes, 1998). It would be interesting to investigate whether this phenomenon applies to online communities, which are usually characterized by more frequent entries and higher turnover than offline communities. Our study finds hints that too many internal social connections are counterproductive, but this effect is true only for extreme values of our social capital measure. However, this result might be due to the relative novelty of the crowdfunding phenomenon: Very few project proponents have backed a very large number of projects before their own launches. As the crowdfunding community grows more stable and interactions become more frequent, we might be able to appreciate more clearly whether homologation and overembeddedness emerge. Third, we ascribe the close association between early contributions and the final success of a crowdfunding campaign to the interplay of observational learning, constructive feedback, and word-of-mouth. However, we are unable to distinguish the effects of these three mechanisms or to assess their relative importance. It would be particularly interesting to investigate the role of constructive feedback because it seems unique to the crowdfunding mode of seed financing. Future work should take a step further in this direction. For instance, it might be interesting to survey early and late backers of crowdfunding projects to understand whether the willingness to pledge is influenced by word-of-mouth, by observing the success of a project in attracting contributions, or by some other motives (such as, e.g., the prospect of joining a lively community of supporters). Fourth, the paper uses data from Kickstarter, which hosts projects from the United States and the United Kingdom. Caution should be taken in generalizing our results to other countries because the social norms governing the behavior of members of crowdfunding communities may be culturally mediated. Furthermore, a data set that includes crowdfunding projects from multiple platforms would allow us to observe whether our results are contingent on a particular platform's rules and setup or could otherwise be generalized in different contexts. Finally, we tested our models on a relatively small sample spanning a limited and not fully representative number of project categories and included only projects posted within a short temporal window. Additional research is needed to verify whether our results hold with more project categories and longer periods.

The paper has interesting implications for both the proponents of crowdfunding projects and the managers of crowdfunding platforms. Our results broadly confirm the view that the early days of a crowdfunding campaign are critical and suggest that proponents should be particularly careful and proactive immediately after the beginning of the campaign. More importantly, we advise proponents that they should not rely exclusively on their external social capital such as family, friends, LinkedIn, and Facebook connections. They should also see crowdfunding platforms as vehicles of rich social interactions that can provide additional social connections beneficial to attracting support for a campaign. Indeed, our findings suggest that internal social capital is more helpful than external social capital. Therefore, we encourage proponents to become embedded in the crowdfunding community by backing other members' projects and by nurturing and 
growing rich social connections. Our results should be good news to project proponents, particularly those that cannot count on numerous and solid family, friendship, and professional relationships. Finally, we show that rewards matter and therefore, designing incentives, particularly those that attract early backers (e.g., discounts, gadgets, and limited editions), seems critical.

Our work also has interesting implications for crowdfunding-platform managers, who are struggling to attract and nurture successful projects. More specifically, our findings suggest that platforms should be regarded not only as intermediaries of funding, but also as intermediaries of social capital both outside and within the platforms themselves. The success of fundraising campaigns depends on proponents' social contacts within generalist social networks such as LinkedIn and Facebook, whereas relationships between proponents and backers are likely to develop into social contacts that trigger specific and generalized reciprocity. It seems important for platform managers to design platform functionalities that enable intense social interactions, strong identification, and a pronounced sense of belonging among project proponents and backers.

\section{REFERENCES}

Adler, P.S. \& Kwon, S. (2002). Social capital: Prospects for a new concept. Academy of Management Review, 27(1), 17-40.

Afuah, A. \& Tucci, C. (2012). Crowdsourcing as a solution to distant search. Academy of Management Review, 37(3), 355-375.

Agrawal, A., Catalini, C., \& Goldfarb, A. (2011). The geography of crowdfunding. NBER Working Paper No. w16820. Cambridge, MA: National Bureau of Economic Research. Available at http://papers.ssrn.com/ sol3/papers.cfm?abstract_id=1770375, accessed July 62014.

Agrawal, A., Catalini, C., \& Goldfarb, A. (2014). Some simple economics of crowdfunding. In J. Lerner, \& S. Stern (Eds.), NBER book series: Innovation policy and the economy (Vol. 14). Chicago: University of Chicago Press.

Ahlers, G.K., Cumming, D., Günther, C., \& Schweizer, D. (2012). Signaling in equity crowdfunding. SSRN Working Paper. Available at http://ssrn.com/abstract=2161587 or http://dx.doi.org/10.2139/ssrn.2161587, accessed 7 July 2014.

Arndt, J. (1967). The role of product-related conversations in the diffusion of a new product. Journal of Marketing Research, 4(3), 291-295.

Banerjee, A.V. (1992). A simple model of herd behavior. Quarterly Journal of Economics, 107(3), $797-817$.

Belleflamme, P., Lambert, T., \& Schwienbacher, A. (2014). Crowdfunding: Tapping the right crowd. Journal of Business Venturing, 29(5), 585-609.

Bikhchandani, S., Hirshleifer, D., \& Welch, I. (1998). Learning from the behavior of others: Conformity, fads, and informational cascades. Journal of Economic Perspectives, 12(3), 151-170.

Bolino, M.C., Turnley, W.H., \& Blooddgood, J.M. (2002). Citizenship behavior and the creation of social capital in organizations. Academy of Management Review, 27(4), 505-522.

Burt, R.S. (2004). Structural holes and good ideas. American Journal of Sociology, 110(2), 349-399.

Cai, H., Chen, Y., \& Fang, H. (2009). Observational learning: Evidence from a randomized natural field experiment. American Economic Review, 99(3), 864-882. 
Cheng, Y.Q., Wang, Q., \& Xie, J. (2011). Online social interactions: A natural experiment on word of mouth versus observational learning. Journal Marketing Research, 48(2), 238-254.

Coleman, J.S. (1990). Foundations of social theory. Cambridge, MA: Harvard University Press.

Dellarocas, C. (2003). The digitization of word of mouth: Promise and challenges of online feedback mechanisms. Management Science, 49(10), 1407-1424.

Duan, W., Gu, B., \& Whinston, H.B. (2009). Information cascades and software adoption on the Internet: An empirical investigation. MIS Quarterly, 33(1), 23-48.

Ender, P. (2006). Stata FAQ: How can I perform mediation with binary variables? Available at http://www .ats.ucla.edu/stat/stata/faq/binary_mediation.htm, accessed August 12013.

Faraj, S. \& Johnson, S.L. (2011). Network exchange patterns in online communities. Organization Science, 22(6), 1464-1480.

Gedajlovic, E., Honig, B., Moore, B., Curt, C.B., Payne, T.G., \& Wright, M. (2013). Social capital and entrepreneurship: A schema and a research agenda. Entrepreneurship Theory and Practice, 37(3), 455-478.

Gerber, E.M., Hui, J.S., \& Kuo, P.Y. (2012). Crowdfunding: Why people are motivated to post and fund projects on crowdfunding platforms. In Proceedings of the International Workshop on Design, Influence, and Social Technologies: Techniques, Impacts and Ethics.

Griffin, J.Z. (2012). Crowdfunding: Fleecing the American mass. Case Western Reserve Journal of Law, Technology \& the Internet. Available at http://ssrn.com/abstract=2030001 or http://dx.doi.org/10.2139/ ssrn.2030001, accessed 7 July 2014.

Hall, B.H. (2002). The financing of research and development. Oxford Review of Economic Policy, 18(1), $35-51$.

Han, J.Y. \& Anat, H. (2013). To bridge or to bond? Diverse social connections in an IS project team. International Journal of Project Management, 31(1), 378-390.

Hartigan, J. \& Hartigan, P. (1985). The dip test of unimodality. Annals of Statistics, 13, 70-84.

Hemer, J. (2011). A snapshot on crowdfunding. Fraunhofer ISI Working Papers Firms and Regions (No. R2/2011). Available at http://www.isi.fraunhofer.de/isi-wAssets/docs/p/de/arbpap_unternehmen_region/ ap_r2_2011.pdf, accessed 7 July 2014.

Hildebrand, T., Puri, M., \& Rocholl, J. (2013). Adverse incentives in crowdfunding. SSRN Working Paper. Available at http://ssrn.com/abstract=1615483, accessed 7 July 2014.

Kale, P., Singh, H., \& Perlmutter, H. (1990). Learning and protection of proprietary assets in strategic alliances: Building relational capital. Strategic Management Journal, 21, 217-237.

Kappel, T. (2009). Ex ante crowdfunding and the recording industry: A model for the U.S. Loyola of Los Angeles. Entertainment Law Review, 3(3), 375-385.

Kauffman, R.J., Lai, H., \& Lin, H. (2011). Consumer adoption of group-buying auctions: An experimental study. Information Technology and Management, 11(4), 191-211.

Kotha, R. \& George, G. (2012). Friends, family, or fools: Entrepreneur experience and its implications for equity distribution and resource mobilization. Journal of Business Venturing, 27(5), 525-543.

Kuppuswamy, V. \& Bayus, B.L. (2013). Crowdfunding creative ideas: The dynamics of project backers in Kickstarter. UNC Kenan-Flagler Research Paper (No. 2013-15). Available at SSRN: http://ssrn.com/ abstract=2234765 or http://dx.doi.org/10.2139/ssrn.2234765, accessed 7 July 2014. 
Leana, C.R. \& Pil, F.K. (2006). Social capital and organizational performance: Evidence from urban public schools. Organization Science, 17(3), 353-366.

Leana, C.R. \& Van Buren, H.J. (1999). Organizational social capital and employment. Academy of Management Review, 24(3), 538-555.

Lin, M., Prabhala, N.R., \& Viswanathan, S. (2013). Judging borrowers by the company they keep: Friendship networks and information asymmetry in online peer-to-peer lending. Management Science, 59(1), 17-35.

MacKinnon, D.P. \& Dwyer, J.H. (1993). Estimating mediated effects in prevention studies. Evaluation Review, 17(2), 144-158.

Markus, L. (1990). Toward a "critical mass" theory of interactive media. In C.S.J. Fulk (Ed.), Organizations and communication technology (pp. 194-218). Newbury Park, CA: Sage.

Maurer, I., Bartsch, V., \& Ebers, M. (2011). The value of intra-organizational social capital: How it fosters knowledge transfer, innovation performance, and growth. Organization Studies, 32(2), 157-185.

McDonald, J.F. \& Moffit, R.A. (1980). The uses of Tobit analysis. Review of Economics and Statistics, 62(2), 318-321.

Metiu, A. \& Kogut, B. (2001). Open-source software development and distributed innovation. Oxford Review of Economic Policy, 17(2), 248-264.

Mollick, E. (2014). The dynamics of crowdfunding: An exploratory study. Journal of Business Venturing, 29(1), 1-16 (http://www.sciencedirect.com/science/article/pii/S088390261300058X).

Nahapiet, J. \& Ghoshal, S. (1998). Social capital, intellectual capital, and the organization. Academy of Management Review, 23(2), 242-266.

Oh, W. \& Jeon, S. (2007). Membership herding and network stability in the open source community: The Ising perspective. Management Science, 53(7), 1086-1101.

Ordanini, A., Miceli, L., Pizzetti, M., \& Parasuraman, A. (2011). Crowd-funding: Transforming customers into investors through innovative service platforms. Journal of Service Management, 22(4), 443-470.

Payne, G.T., Moore, B.C., Griffis, S.E., \& Autry, C.W. (2011). Multilevel challenges and opportunities in social capital research. Journal of Management, 37(2), 491-520.

Portes, A. (1998). Social capital: Its origins and applications in modern sociology. Annual Review of Sociology, 4, 1-24.

Putnam, R.D. (1995). Bowling alone: America's declining social capital. Journal of Democracy, 6(1), 65-78.

Rowley, T.B. (2000). Redundant governance structures: An analysis of structural and relational embeddedness in the steel and semiconductor industries. Strategic Management Journal, 21(3), 369-386.

Salganik, M.J., Dodds, P.S., \& Watts, D.J. (2006). Experimental study of inequality and unpredictability in an artificial cultural market. Science, 311, 854-856.

Schelling, T.C. (1978). Micromotives and macrobehavior. New York: W.W. Norton.

Shane, S. \& Cable, D. (2002). Network ties, reputation, and the financing of new ventures. Management Science, 48(3), 364-381.

Shane, S. \& Stuart, T. (2002). Organizational Endowments and the Performance of University Start-ups. Management Science, 48(1), 154-170.

Shane, S.A. (2009). Fool's gold? New York: Oxford University Press. 
Simonsohn, U. \& Ariely, D. (2008). When rational sellers face nonrational buyers: Evidence from herding on eBay. Management Science, 54(9), 1624-1637.

Sobel, M.E. (1982). Asymptotic confidence intervals for indirect effects in structural equation models. Sociological Methodology, 13, 290-312.

Spence, M. (2002). Signaling in retrospect and the informational structure of markets. American Economic Review, 92(3), 434-459.

The Economist. (2013). Winning over the crowd. What works, and what doesn't, on the biggest crowdfunding site. Available at http://www.economist.com/blogs/graphicdetail/2013/01/daily-chart-12, accessed 7 January 2013.

Tsai, W. \& Ghoshal, S. (1998). Social capital and value creation: The role of intrafirm networks. The Academy of Management Journal, 41(4), 464-476.

von Krogh, G., Rossi-Lamastra, C., \& Haefliger, S. (2012). Phenomenon-based research in management and organization science: When is it rigorous and does it matter. Long Range Planning, 45(4), 277-298.

Wasko, M.M. \& Faraj, S. (2005). Why should I share? Examining social capital and knowledge contribution in electronic network of practice. MIS Quarterly, 29(1), 35-57.

Westlund, H., Rutten, R., \& Boekema, F. (2010). Social capital, distance, borders and levels of space: Conclusions and further issues. European Planning Studies, 18(6), 965-969.

Zhang, J. \& Liu, P. (2012). Rational herding in microloan markets. Management Science, 58(5), 892-912.

Massimo G. Colombo is full professor of economics of innovation at the Department of Management, Economics and Industrial Engineering, Politecnico di Milano, P. Leonardo da Vinci 32, Milano 20133, Italy.

Chiara Franzoni is assistant professor at the Department of Management, Economics and Industrial Engineering, Politecnico di Milano, P. Leonardo da Vinci 32, Milano 20133, Italy.

Cristina Rossi-Lamastra is assistant professor at the Department of Management, Economics and Industrial Engineering, Politecnico di Milano, P. Leonardo da Vinci 32, Milano 20133, Italy.

The authors acknowledge support from the EU-FP7 Framework Program, under the grant "Creativity for Innovation and Growth in Europe." They wish to thank Oliver Alexy, Sharon Alvarez, Tom Astebro, Jay Barney, Andrea Contri, Giambattista Dagnino, David Drake, Gary Dushnitsky, Arabella Mocciaro Li Destri, Eric Von Hippel, Samuele Murtinu, Evila Piva, Christina Raasch, and the participants at the 4th HEC Workshop on Entrepreneurship (4-5 October 2013) for their insightful comments. Chiara Basanisi, Vincenzo Butticè, Alberto Carenzi, and Daniela Ceresa provided excellent research assistantship in collecting data. Responsibility for any errors rests solely with the authors. 